\title{
PENERAPAN MODEL PENDIDIKAN KARAKTER BERBASIS“5 KARAKTER WAJIB TARUNA” SMK Negeri 13 MALANG
}

\author{
Heka Fitria Fujiyama, Rohmad Widodo, Trisakti Handayani \\ FKIP Universitas Muhammadiyah Malang, Indonesia \\ Email: heka_fitria@gmail.com
}

\begin{abstract}
ABSTRAK
Pendidikan karakter muncul akhir-akhir ini, setelah terjadi degradasi moral yang melanda bangsa Indonesia. Pendidikan karakter pada prinsipsinya adalah sebagai upaya menumbuhkan kepekaan dan tanggung jawab sosial, membangun kecerdasan emosional, dan mewujudkan peserta didik memiliki etika yang tinggi. Penelitian ini bertujuan untuk mendiskripsikan: (1) penerapan pendidikan karakter berbasis 5 karakter wajib taruna SMK Negeri 13 Malang, (2) kendala yang dihadapi dalam penerapan pendidikan karakter berbasis 5 karakter wajib taruna, (3) solusi yang dapat dilakukan dalam penerapan pendidikan karakter berbasis 5 karakter berbasis 5 karakter wajib taruna. Penelitian ini menggunakan teknik penelitian kualitatif dengan prosedur penelitian yang menghasilkan data deskriptif berupa kata-kata tertulis atau lisan orang-orang dan perilaku yang dihadapi. Pengumupulan data diperoleh dengan teknik wawancara, observasi, dan dokumentasi. Tahapantahapandalamanalisis data dilakukandengancara: pengumpulan data, reduksi data, penyajian data danpenarikankesimpulan. Uji keabsahan data dilakukan denganteknikkredibilitas, transferbilitas, debendabilitasdankonfirmabilitas.Berdasarkan penelitian ini dapat diperoleh hasil penelitian yaitu: (1) Penerapan pendidikan karakter berbasis 5 karakter wajib taruna diterapkan dalam kegiatan sehari-hari dari taat, jujur, disiplin, bekerjasama dan berprestasi. 5 karakter diterapkan dalam semua aspek kehidupan di lingkungan sekolah. (2) Kendala yang dihadapi dalam penerapan pendidikan karakter berbasis 5 karakter wajib taruna diantaranya; belum ada kesadraan penuh dalam diri taruna sehingga kecenderungan sulit menerapkan pendidikan karakter berbasis 5 karakter wajib taruna, masih adanya guru yang tidak mendukung, kurang pengawasan orang tua dirumah. (3) Solusi yang dapat dilakukan dalam penerapan pendidikan karakter berbasis 5 karakter wajib taruna yakni memberikan pencegahan secara preventif melalui buku saku dan al-kays, melakukan koodinasi antara pihak sekolah dan orang tua, melakukan konsultasi kepada taruna-taruni oleh staff batalyon, kontrol sikap taruna-taruni melalui bimbingan konseling.
\end{abstract}

Kata Kunci : "5 karakter wajib taruna”

\begin{abstract}
Nowadays, character building in education is commonly spoken, let alone after degradation of the youth moral in Indonesia. Principally, character building is an attempt to grow the sensitivity and social responsibility, to build the emotional intelegence, and to create students with high attitude. This research is aimed to describe: (1) the implementation of character building in education based on the 5 obligatory characters of school with military based in SMKN 13 Malang, (2) the problems that are faced in implementing the character building in education based on the 5 obligatory characters of school with military based, (3) the ways to cope with the problems in implementing the character building in education based on the 5 obligatory characters of school military based. This research employed the qualitative research that produces the descriptive data which are written or oral data, and the attitude of the students. The data colllection techniques that were used: interview, observation, and documentation. The steps in analayzing the data were: collecting the data, reduction data, findings, and drawing the
\end{abstract}


conclusion. The validity test were done by using credibility,trasnferable, dependable, and confirmable techniques. Based on the analysis, it can be drawn several results as follows: (1) 5 obligatory character of students was implemented in daily activities at school: obedient, honest, discipline, cooperate, and be an achiever.All students in education based military were taught about 5 obligatory characters which were implemented in every aspect at school. (2) The problems which were faced during the character building implementation were: there was no high awareness of students in implementing 5 obligatory characters. There was lack of support from teachers and parents at house. (3) The ways to cope with the problems which were implemented: gave the preventive ways through pocket book called al-kays, built cooperation between school side and parents, did consultation between students and staff battalion, attitude control of students through counseling advisory.

Key words: "5 obligatory characters of school with military based"

\section{PENDAHULUAN}

Pendidikan bagi kehidupan manusia merupakan kebutuhan mutlak yang harus dipenuhi sepanjang hayat. Pendidikan harus dikelola dengan tertib, teratur, efektif dan efisien sebagai pendukung utama dalam membangun karakter bangsa. Hal ini sesuai dengan Undang-Undang No. 20 tahun 2003 pada pasal 3, yang menyebutkan : “ Pendidikan nasional berfungsi mengembangkan kemampuan dan membentuk watak serta peradaban bangsa yang bermartabat dalam rangka mencerdaskan kehidupan bangsa, bertujuan untuk berkembangnya potensi peserta didik agar menjadi manusia yang beriman dan bertakwa kepada Tuhan Yang Maha Esa berakhlak mulia, sehat, berilmu, cakap, kreatif, mandiri, dan menjadi warga negara yang demokratis serta bertanggung jawab”. Dalam Undang-Undang tersebut dapat dipahami tujuan dari Sistem Pendidikan Nasional pada intinya ialah suatu bentuk bimbingan dan pengembangan potensi peserta didik agar menjadi manusia yang beriman dan bertakwa Kepada Tuhan Yang Maha Esa, Kesadaran peserta didik untuk menjadikan hidupnya terarah dengan baik dan mampu menjadi kepribadian yang berkarakter kuat tertanam pada pribadinya dalam kehidupan sehari-hari. pendidikan karakter muncul kepermukaan akhir-akhir ini, setelah terjadi degradasi moral yang melanda bangsa Indonesia. Menurut Fadilllah \& Khorida (2013:16), pendidikan karakter, terambil dari dua suku kata yang berbeda, yaitu pendidikan dan karakter. Kedua kata ini mengandung makna sendirisendiri.

Karakter memberikan gambaran tentang suatu bangsa, sebagai penanda, penciri sekaligus pembeda suatu bangsa dengan bangsa lainya. Karakter memberikan arahan tentang bagaimana bangsa menapaki dan melewati suatu jaman dan mengantarkanya pada suatu derajat tertentu. Karakter suatu bangsa ditentukan dari karakter setiap individunya hal itu menandakan bahwa karakter memiliki kekuatan yang sangat luar biasa untuk menumbuhkan dan memperkuat jati diri bangsa. Terbentuknya karakter yang kuat dan kokoh menjadi hal yang utama untuk dimiliki peserta didik dalam menghadapi tantangan hidup di masa sekarang ataupun di masa yang akan datang. Pendidikan karakter diperoleh sejak pendidikan usia dini hingga perguruan tinggi sehingga dapat mencetak peserta didik menjadi pribadi yang unggul guna mencapai tujuan pendidikan nasional yang ditetapkan. Dirjen Dikti dalam Arifin M, \& Barnawi 
(2012:24), pendidikan karakter dapat dimaknai sebagai pendidikan nilai, pendidikan budi pekerti, pendidikan moral, pendidikan watak, yang bertujuan mengembangkan kemampuan peserta didik untuk memberikan keputusan baik buruk, memelihara apa yang baik, mewujudkan, dan menebar kebaikan itu dalam kehidupan sehari-hari dengan sepenuh hati.

Thomas Lichona dalam Muslich (2011:35) Akhir-akhir ini muncul fenomena-fenomena di kalangan pendidikan yang sudah cukup memprihatinkan. Berbagai tindakan negatif banyak terjadi di kalangan pelajar. Tindakan negatif yang dimaksud seperti (1) meningkatnya kekerasan di kalangan remaja, seperti tawuran antar pelajar, (2) penggunaan bahasa dan kata-kata yang buruk, (3) meningkatnya perilaku yang merusak diri, seperti narkoba, alkohol dan seks bebas, (4) semakin hilangnya pedoman moral yang baik, (5) semakin rendahnya rasa hormat terhadap orang tua dan guru, (5) Rendahnya rasa tanggung jawab pada setiap individu dan warga negara, (6) rendahnya sifat ketidak jujuran, (7) Adanya rasa curiga dan kebencian antar teman dll, Thomas Lichona dalam Muslich (2011:35). Melihat realitas tersebut, dapat dilihat dengan jelas bahwa generasi bangsa kita telah mengalami degradasi peran dan fungsinya. Hal ini terbukti dengan adanya peristiwa tawuran antar pelajar hingga menelan korban jiwa, bahkan penggunaan obat-obatan terlarang marak dikalangan pelajar, perilaku seks bebas dan pemerkosaan pun sering terjadi pada pelajar sekolah. Hal-hal tersebut bila dibirkan terus menerus akan akan menjadi budaya negatif dan merusak pola pikir generasi muda. Seorang pelajar adalah generasi yang disiapkan untuk menjadi pembaharu untuk membawa bangsa ke arah yang lebih baik. Lalu bagaimana seorang pelajar mejalankan fungsi dan perannya sebagai generasi bangsa, apabila masih banyak di temukan budaya-budaya negatif yang dilakukan oleh generasi muda. Budaya-budaya negatif tersebut menandakan bahwa telah terjadi krisis moral di dalam sistem pendidikan saat ini.

Pendidikan karakter disini diharap mampu menjadi alternatif dan solusi untuk krisis moral dan etika yang saat ini terjadi. Pendidikan karakter seharusnya mulai di tanamkan pada peserta didik agar tidak terjebak pada budaya negatif. Berkaitan dengan itu setiap institusi pendidikan terutama sekolah harus menekankan dan menerapkan pendidikan karakter khusunya kepada pribadi peserta didik, karena hal itu sebagai upaya dan jawaban dari permasalahan terkait krisis moral yang saat ini terjadi. Maka perlu dilakukan berbagai program terobosan yang terus menerus untuk mensosialisasikan pendidikan karakter, sehingga langkah-langkah yang diharapkan dapat diterapkan dengan baik. Program terobosan yang dimaksud adalah program pendidikan karakter yang dirancang sekolah untuk diterapkan kepada peserta didik selama berada dilingkungan sekolah, hal ini dilakukan dari proses kegiatan belajar mengajar (KBM) maupun kegiatan-kegitan di luar kelas yang relavan untuk pengembangan nilai-nilai pendidikan karakter, sehingga nilai-nilai yang diterapkan dalam pendidikan karakter bermanfaat bagi peserta didik.

Pendidikan Karakter dapat diterapkan di lingkungan sekolah sebab sekolah merupakan salah satu sarana bagi pendidikan, yang mentransformasikan ilmu dari guru kepada peserta didik. Pembelajaran di sekolah bertujuan untuk menangkis pengaruh budaya-budaya negatif, menanamkan pemahaman dan 
penghayatan nilai kemanusiaan dan ketuhanan untuk menjadikan diri setiap peserta didik menjadi manusia yang berkarakter kuat dan berbudi pekerti luhur.

Studi pendahuluan dan fakta di lapangan SMK Negeri 13 Malang cukup antusias dalam proses pendidikan karakter, sekolah dengan basis taruna ini memiliki program trobosan untuk mendidik taruna dan taruni menjadi pribadi yang kuat dalam sikap maupun perilakunya. Hal ini terlihat jelas dalam program terobosan sekolah yakni pendidikan karakter melalui 5 karakter wajib taruna SMK Negeri 13 Malang. 5 karakter wajib taruna antara lain : taat, jujur, disiplin, bekerjasama dan berprestasi. 5 karakter wajib taruna SMK Negeri 13 Malang dibuat dari 5 pantangan yang tidak boleh dilakukan oleh taruna dan taruni SMK Negeri 13 Malang, 5 pantangan yang tidak boleh dilakukan antara lain : menolak tugas, pantang berbohong, pantang terlambat, pantang konflik dan pantang menyerah. Berdasarkan hal tersebut tampak secara jelas bahwa SMK Negeri 13 Malang merupakan tempat bagi generasi muda untuk menjadi manusia terbaik. Selain itu Visi SMK Negeri 13 Malang unggul spiritual, IPTEK, berbudayanusantara, danberwawasan global. Dapat dilihat dari visi sekolah tersebut bahwa taruna-taruni, guru dan karyawan dibekali dengan spiritual budaya nusantara yang kuat, serta berwawasan global. SMK Negeri 13 Malang juga menerapkan pendidikan ketarunaan yang wajib diikuti oleh setiap taruna dan taruni, kegiatan wajib tersebut diterapkan sebagai salah satu sarana dalam mendidik taruna dan taruni yang disiplin, berjiwa kesatria serta bertanggung jawab terhadap semua perbuatan yang dilakukan dalam kehidupan sehari-hari di lingkungan sekolah maupun di lingkungan masyarakat.

Tingkat pelanggaran tata tertib yang dilakukan oleh taruna dan taruni di SMK Negeri 13 Malang yang cukup sering terjadi adalah terlambat, lupa membawa buku saku, dan tidak memakai atribut lengkap dalam berseragam. Setiap pelanggaran maupun prestasi yang dilakukan oleh taruna dan taruni terekam dalam buku saku, buku saku adalah buku yang berfungsi untuk mencatat prestasi dan pelanggaran disiplin taruna, buku tersebut memberikan point pelanggaran bagi taruna yang melanggar dan juga memberikan point prestasi bagi yang berprestasi, setiap point dalam pelanggaran maupun prestasi berbeda dan sudah tercatat masing-masing pasal pada setiap buku saku. Bagi taruna dan taruni yang melanggar peraturan, sekolah memberikan sanksi yang mendidik misalnya bagi taruna atau taruni yang terlambat mereka diwajibkan untuk membawa bunga, dan mendapat catatan pelanggaran pada buku saku, sebaliknya bagi taruna dan taruni yang mendapatkan prestasi juga mendapat point prestasi sesuai dengan tingkat prestasi yang didapatkan. Hal tersebut tentunya tidak lepas dari peran sekolah untuk memberikan pengajaran bagi taruna dan taruni bahwa setiap perbuatan baik itu positif maupun negatif akan mendapatkan konsekuensi sesuai dengan apa yang dilakukannya, sehingga sikap disiplin, tanggung jawab, dan taat akan tertanam pada diri setiap taruna dan taruni sebagai bentuk penanaman nilai-nilai dari pendidikan karakter SMK Negeri 13 Malang.

Berdasarkan uraian diatas maka peneliti tertarik untuk melakukan penelitian dengan mengambil judul "Penerapan Pendidikan Karakter Berbasis 5 Karakter Wajib Taruna SMK Negeri 13 Malang”. 


\section{METODE}

Pendekatan penelitian yang digunakan dalam penelitian ini adalah pendekaatan kualitatif. Pendekatan kualitatif adalah penelitian yang bersifat deskriptif dan cenderung menggunakan analisis dengan menggunakan induktif. Penelitian kualitatif adalah prosedur penelitian yang menghasilkan data deskriptif (Bogdan \& Tylor dalam zuriah, 2009:92).

Pendekatan kualitatif adalah pendekatan dengan desain penelitian kebijakan oleh karena itu jenis penelitian yang digunakan adalah jenis penelitian yang menghasilkan kata-kata tertulis atau lisan dari orang-orang dan datanya dikumpulkan berupa tulisan, kata-kata, gambar dan bukan angka-angka (Bogdan \& Tylor dalam zuriah, 2009:92). Penelitian tersebut dimaksudkan untuk mengungkapkan gejala-gejala melalui pengumpulan data dari lapangan sebagai instrumen penelitian. Penelitian kualitatif bersifat deskriptif dan cenderung menggunkan analisis dengan pendekatan induktif.

Penelitian ini dilakukan menggunakan pendekatan kualitatif, karena ada beberapa hal yang dipertimbangkan antara lain : 1). Prosedur penelitian kualitatif lebih mudah; 2). Bisa lebih dekat dengan data penelitian ketika langsung terjun kelapangan, jenis dan pendekatan kualitatif ini untuk mencari data mengenai Penerapan Model Pendidikan Karakter Berbasis 5 Karakter SMK Negeri 13 Malang.

Sesuai dengan pendekatan kualitatif yang digunakan untuk proses pengumpulan data dilakukan oleh peneliti sendiri. Sugiono (2010:306), menyatakan penelitian kualitatif sebagai human instrument, berfungsi menetapkan fokus penelitian, memilih informan sebagai sumber data, melakukan pengumpulana data, menilai kualitas data, analisis data, menafsirkan data dan membuat kesimpulan atas temuannya.

\section{HASIL DAN PEMBAHASAN}

Berdasarkan Undang-Undang Nomor 20 pasal 3 Tahun 2003 bahwa tujuan dari sistem pendidikan nasional pada intinya ialah suatu bentuk bimbingan dan pengembangan potensi peserta didik supaya terarah dan mampu menjadi pribadi yang berkarakter kuat. SMK Negeri 13 Malang merupakan salah satu sekolah berbasis taruna yang berusaha memberikan pendidikan karakter melalui pendidikan karakter berbasis 5 karakter wajib taruna SMK Negeri 13 Malang. Berdasarkan observasi, wawancara dan dokumentasi diperoleh hasil pembahasan sebagai berikut:

\section{Penerapan Pendidikan Karakter Berbasis 5 Karakter Wajib Taruna SMK Negeri 13 Malang}

Setiap lembaga pendidikan dalam hal ini sekolah, pasti akan memberikan pengajaran yang positif terhadap peserta didiknya. Salah satu hal yang positif yang diberikan sekolah terhadap peserta didiknya adalah pendidikan karakter. Setiap sekolah pasti menerapkan pendidikan karakter kepada peserta didiknya sebagai upaya dan bentuk bimbingan dalam melahirkan generasi-generasi muda yang berkarakter kuat dalam sikap maupun perilakunya. Oleh sebab itu, peran sekolah sangat penting dalam hal menyisipkan pendidikan karakter disetiap pembelajaran. Penerapan pendidikan karakter berbasis 5 karakter wajib taruna begitu penting sebab dapat menjadikan taruna-taruni SMK Negeri 13 Malang berbudi pekerti luhur dan berkarakter kuat. SMK Negeri 13 Malang merupakan salah satu sekolah yang menerapkan pendidikan karakter. Pendidikan karakter yang diterapkan di SMK Negeri 13 Malang yakni pendidikan karakter berbasis 5 karakter wajib taruna.

Pendidikan karakter berbasis 5 karakter wajib taruna merupakan

Heka Fitria Fujiy, dkk. Penerapan Model Pendidikan Karakter Berbasis

"5 Karakter Wajib Taruna" SMK Negeri 13 Malang 
pendidikan karakter yang mengacu pada 5 nilai yaitu 1 . taat 2 . jujur 3. disiplin 4 . bekerjasama dan 5. Berprestasi, dari keli ma nilai itu diterapkan dan diaplikasikan dalam kegiatan sehari-hari. Hal tersebut di dukung dengan hasil observasi dan dokumentasi lapangan, terkait penerapan pendidikan karakter berbasis 5 wajib taruna dalam kegiatan-kegiatan sebagai berikut:

1) Apel pagi

Kegiatan awal pembelajaran dimulai dengan apel pagi bagi seluruh warga sekolah. Apel pagi merupakan kegiatan rutin yang dilaksanakan setiap hari, dimulai pukul 06.30 WIB. Di dalam kegiatan apel pagi masing-masing ketua kelas melakukan laporan terlebih dahulu kepada pembina apel untuk memberi laporan berapa jumblah anggota kelas yang tidak hadir, bagi tarunataruni yang datang terlambat dan tidak mengikuti apel pagi akan mendapatkan sanksi berupa point pelanggaran pada buku saku, dan membawa bunga sebagai sanksi dari pelanggaran tersebut. Kegiatan apel pagi dilaksankan sebagai bentuk dari penerapan karakter pertama yakni "taat" diharapkan semua warga sekolah termasuk juga taruna-taruni selalu taat untuk mengikuti kegiatan apel. Ketika karakter yang pertama "taat" dijalankan otomatis mereka disiplin yakni juga menerapkan karakter yang ketiga.

2) Imtaq, Tutor sebaya, Hatam AlQur'an bagi muslim dan Kebaktian bagi taruna non muslim

Kegiatan pembinaan keimanan dan ketaqwaan kepada Tuhan Yang Maha Esa salah satunya diterapkan melalui Imtaq, Tutor sebaya dan Hatam Al-Qur'an, ketiga kegiatan tersebut dilaksanakan sebagai upaya untuk membentuk keimanan bagi seluruh taruna-taruni agar membiasakan diri untuk membaca Asmaul Husna dan Al-Qur'an. Ketiga kegiatan tersebut dilaksanakan secara berkelanjutan dimulai dari Imtaq dilaksankan setiap pagi sebelum proses belajar mengajar dikelas, tutor sebaya dilakukan setiap hari jumat pagi bagi taruna yang sudah lancar membaca diupayakan untuk memberi pengajaran bagi taruna yang belum lancar membaca Alqur'an, dari imtaq dan tutor sebaya dilanjutkan dengan hatam Al-Qur'an dalam waktu 1 bulan sekali. Selanjutnya taruna yang beragama nasrani melakukan kajian kitab dibawah bimbingan guru yang seiman.

Imtaq bagi yang beragama muslim dan kajian kitab umat nasrani diprogramkan untuk diterapkan setiap hari. hal tersebut untuk menerapkan karakter yang pertma yakni “ taat” taat kepada Tuhan Yang Maha Esa dengan melaksankan kegiatan keagamaan maka taruna akan terbiasa untuk beribadah kepada Tuhan-NYA sesuai keyakinan dan kepercayaan masing-masing. 3) Pemeriksaan seragam, atribut dan buku saku oleh staff batalyon

Pemeriksaan seragam, atribut dan buku saku dilakukan oleh staff batalyon, staff batalyon adalah taruna yang terpilih dan diberi tugas sebagai kendali mutu disiplin taruna. Pengecekan tersebut dilakukan untuk menghimbau agar setiap taruna SMK Negeri 13 Malang berpakaian sesuai dengan ketentuan yang berlaku dan buku saku merupakan buku yang harus dibawa setiap saat selama di lingkungan sekolah, karena berfungsi untuk mencatat prestasi dan pelanggaran disiplin taruna.

Memakai seragam lengkat, atribut dan membawa buku saku merupakan bentuk penanaman kataatan dan kedisiplinan yang ditanamkan oleh sekolah kepada taruna. Kegiatan tersebut dilakukan selain sebagai bentuk upaya pembiasaan juga sebagai penerapaan karakter pertama “ taat” untuk taat kepada peraturan sekolah dan penerapan karakter yang ketiga yakni "disiplin" disiplin terhadap semua bentuk peraturan sekolah. 
4) Sholat Dhuha dan Shlat Dzuhur Berjama'ah

Kegiatan Peningkatan Keimana dan Keimanan kepada Tuhan Yang Maha Esa tidak hanya dilakukan di Imtaq saja tetapi juga dilaksanakan pada saat istrahat pertama yaitu dengan melaksanakan shalat dhuha berjamaah dan pada saat istrahat kedua shalat dzuhur berjamaah. Penerapan kegiatan tersebut diberi buku panduan (Al-kays) untuk mencegah supaya tidak terjadi pelanggaran dengan meminta tanda tangan guru pembimbing atau Kepala Sekolah setelah melaksankan ibadah sholat dhuha dan dzuhur.

Shalat dhuha dan dzuhur berjamaah sebagai bentuk kegiatan wajib agar taruna membiasakan diri untuk selalu melaksankan ibadah, oleh sebab itu shalat dhuha dan dzuhur berjamaah menjadi kewajiban dan kegiatan dari penerapan pendidikan karakter berbasis 5 karakter wajib taruna yang merupakan karakter pertama yakni “taat” taat kepada Tuhan Yang Maha Esa.

5) Memberikan Penghormatan kepada guru dan atasan (senior)

Taruna SMK Negeri 13 Malang memiliki kewajiban untukmenjunjung tinggi kehormatan, dengan memberikan penghormatan kepada Kepala sekolah, Pembina, Pendidik (guru), tamu dan juga senior. Senior adalah salah satu yang juga diwajibkan untuk diberikan penghormatan sebab SMK Negeri 13 Malang menganut asas senioritas. Penghormatan dilakukan dikelas sebelum pembelajaran dimulai dan diluar kelas ketika berpapasan, melakukan penghormatan hanya pada saat memakai pakaian dinas.

Penghormatan yang dilakukan sebagai bentuk pembiasaan taruna-taruna untuk memiliki karakter taruna sejati, penghormatan tersebut juga sebagai penerapan karakter pertama "taat” untuk taat kepada guru, senior dan semua orang yang wajib untuk dihormati.
6) Kegiatan Ketarunaan

Ketarunaan adalah pendidikan dan Latihan Dasar Taruna (LATDASTAR) yang wajib diikuti bagi semua taruna-taruni SMK Negeri 13 Malang pada setiap rabu dan kamis setelah jam pembelajaran selesai. Latihan Dasar tersebut dilakukan untuk melatih karakter setiap anak agar menjadi taruna yang disiplin dan mempunyai bejiwa kesatria, latihan dasar taruna ini dibimbing langsung oleh pihak LANAL dalam rangka memberi materi ketarunaan.

Kegiatan ketarunaan yang diterapkan merupakan karakter ketiga yakni “disiplin”, kegiatan tersebut sebagai upaya pembentukan dan pembiasaan disiplin sikap, mental dan perilaku agar menjadi taruna yang tangguh dan berjiwa kesatria. 7) Sholat jum'at dan Kajian keputrian

Sholat jum'at adalah salah satu kegiatan yang wajib dilakukan oleh taruna, dan keputrian dilakukan oleh taruni. Kegitan ini dilakukan untuk memperdalam Ketaqwaan dan Keimanan para taruna SMK Negeri 13 Malang untuk selalu beribadah kepada Allah SWT.

8) Upacara Bendera

Bentuk bimbingan yang diberikan Sekolah untuk membentuk sikap mencintai dan mengormati kepada Negara Indonesia salah satunya dengan melakukan upacara bendera. Upacara bendera dilakukan rutin setiap hari senin dan pada hari-hari besar bersejarah seperti hari kesaktian pancasila, hari pahlawan dll, dengan pelaksanaan tersebut diharapkan taruna-taruni akan menambah rasa nasionalisme terhadap Negara Indonesia.

Pelaksaan upacara merupakan bentuk penerapan karakter pertama yakni “Taat” taat kepada negara Indonesia dengan melaksanakan upacara bendera sekolah menanamkan bentuk ketaatan kepada negara sehinga taruna akan mengormati dan mencintai Negara Indonesia.

Heka Fitria Fujiy, dkk. Penerapan Model Pendidikan Karakter Berbasis

"5 Karakter Wajib Taruna" SMK Negeri 13 Malang 
9) Setiap sudut sekolah dipasang dengan kata-kata Mutiara, Semboyan dan Himbauan

Sekolah SMK Negeri 13 Malang mengupayakan taruna selalu memiliki karakter yang baik, upaya yang dilakukan sekolah selain melalui kegiatan nyata juga dilakukan melalui himbauan, semboyan maupun kata-kata mutiara hal ini dilakukan agar taruna-taruni dapat menghayati setiap kata-kata tersebut agar dapat menyatu dengan dirinya.

10) Merayakan Hari Besar Keagamaan

Hari keagamaan merupakan suatu wujud uacapan trimakasih yang diajarkan Sekolah keapada taruna untuk selalu bersyukur keapada Tuhan Yang Maha Esa, sekolah mengajarkan dapat merayakan hari besar tersebut bersama-sama. Salah satu perayaan yang rutin dilakukan di sekolah adalah merayakan Hari Raya Idul Adha dalam kegiatan ini setiap kelas dwajibkan untuk memberikan sedikit rezekinya untuk dibagikan keapada sesama.

Perayaan hari raya Idul Adha, kegiatan perayaan tidak dilakukan dengan penyembelihan hewan qurban saja mealinkan juga dengan kegiatan istiqosah bersama yang dilanjutkan halal bihalal seperti yang ada pada gambar diatas. Hal tersebut dilakukan untuk memupuk karakter yang ketiga yakni "bekerjasama" agar seluruh taruna beserta guru serta karyawan SMK Negeri 13 Malang dapat saling bersilahturahmi dengan baik, menjalin hubungan baik sehingga kerjasama juga bisa dilakukan dengan baik.

11) Laporan kepada guru sebelum dimulai pembelajaran

Salah satu standar taruna adalah melakukan laporan terlebih dahulu sebelum memulai kegiatan belajar mengajar (KBM) hal ini dilakukan oleh taruna sebagai bentuk dari seorang taruna yang menghormati setiap guru yang ada disekolah. Laporan dilakukan dengan hormat terlebih dahulu kemudian memberitahukan berapa jumblah siswa yang hadir dan berapa siswa yang tidak hadir dengan laporan berarti seluruh kelas sudah siap untuk mengikuti pembelajaran. Laporan tersebut dilakukan sebagai bentuk penanaman disiplin dan ketaatan kepada pendidik, yang wajib dan selalu dilakukan oleh taruna.

12) Kegiatan Ekstakurikuler

Kegiatan esktrakulikuler yang dikembangkan di SMK Negeri 13 Malang ada enam disesuaikan dengan minat dan jumblah siswa, ekstrakulikuler wajibnya adalah pramuka, pramuka dilakukan pada hari jum'at, dan kegiatan lainya dilakukan pada hari sabtu setelah jam pembelajaran dikelas berakhir kegiatan ekstrakulikuler yang meliputi: karate, tari, futsal, PMR dan BDI.

Kegiatan ekstra dilakukan sebagai pembinaan agar taruna dapat berprestasi tidak hanya akademik saja melainkan non akademik. Berprestasi adalah karakter kelima yang terus dibimbing selain melalui pembelajaran hal lainya juga dilakukan melalui kegiatan ekstrakulikuler.

13) Masuk kelas sesuai dengan standar Taruna

Untuk menumbuhkan jiwa korps dan kebersamaan di lingkungan kelas salah satunya dilakukan dengan cara barisberbaris sesuai dengan standart taruna. Baris-berbaris yang dilakukan oleh taruna SMK Negeri 13 Malang dilakukan dengan perhitungan atribut dari atas hingga bawah. Taruna tidak dilakukan hanya pada saat kegiatan ketarunaan saja melainkan juga dipupuk dalam kegiatan sehari-hari termasuk pada saat taruna akan memasuki kelas. 
14) Kegiatan Pembelajaran berbasis lesson study

Dalam upaya peningkatan proses pembelajaran dan keprofesionalan guru, sekolah mengembangkan kegiatan lesson study berbasis sekolah yang langsung dimonitoring dan dievalusi secara berkala oleh kepala sekolah. Kegiatan lesson study yang terdiri dari 3 tahapan do, si dan reveleksi telah terbukti membuat guru saling belajar dan tidak terikat dengan senioritas. Kerjasama adalah wujud dari penerapan karakter wajib taruna ke 4. Lesson study dilakukan untuk membangun kerjasama dan saling menghargai antara guru sebagai proses monitoring profesional guru, sehingga siswa juga ikut termotifasi untuk menjalin kerjasama dan membangun hubungan yang selaras antara taruna SMK Negeri 13 Malang. Pembelajaran berbasis lesson study dilakukan secara berkala 1 minggu sekali.

Kegiatan lesson study yang dilakukan terbukti selain sebagai peningkatan proses kegiatan belajar menagajar juga dapat membangun hubungan kerjasama yang baik antara kepala sekolah, bapak ibu guru dan juga taruna SMK Negeri 13 Malang.

15) Kegiatan LDK

Latihan dasar kepemimpinan adalah kegiatan yang diperuntunkan untuk staff batalyon, staff batalyon adalah taruna yang dipilih dan diberi tugas sebagai kendali mutu disiplin taruna. Kegiatan LDK berfungsi untuk memberikan pengetahuan organisasi dan membekali jiwa kepemimpinan bagi setiap taruna yang terpilih. Kegiatan LDK dilakukan sesuai dengan standart taruna yaitu mendisiplinkan seluruh staff batalyon agar menjadi melaksanakan tugas secara adil, tanggung jawab dan berdedikasi tinggi mengingat staff batalyon adalah organisasi tertinggi di SMK Negeri 13 Malang.
Kegiatan LDK wajib diikuti oleh staff batlyon sebelum masa jabatan sebab hal itu menjadi salah satu pembelajaran, dan proses pelatihan tanggung jawab agar nantinya mampu mengemban tugas dengan baik.

16) Kegiatan Aksi hijau

Kegiatan aksi hijau dilakukan untuk menjaga dan melestarikan kebersihan lingkungan sekolah sebab kebersihan sekolah menjadi tanggung jawab seluruh warga sekolah. Salah satu kegiatan trobosan untuk menjaga kebersihan dan membiasakan warga sekolah untuk menjaga kebersihan lingkungan adalah dengan menerapkan kegiatan aksi hijau. Aksi hijau sendiri dilakukan dengan memilih member go green school, member diberi tugas untuk memantau kebersihan dan untuk menghimbau seluruh warga sekolah dari guru, taruna hingga karyawan untuk bergotong royong dalam kebersihan.

Kegiatan aksi hijau yang dilakukan selain untuk menjaga dan melestarikan lingkungan sekolah, kegiatan ini dirasa mampu memupuk karakter yang ke 4 yakni bekerjasama, dengan melaksankan kegiatan kasi hijau secara teratur maka kerjasama antara seluruh warga sekolah kan terjalin dengan baik.

Nilai-nilai tersebut diharapkan untuk memberikan pedoman dalam pembinaan kepribadian taruna yang diterapkan diproses pembelajaran selama berada disekolah dan diaplikasikan dalam bentuk tingkah laku setiap hari yang akan dibawa sepanjang hidup.

Manfaat dari pendidikan karakter adalah membentuk dan membangun pola pikir, sikap dan perilaku untuk selalu bersikap dengan baik, baik kepada Tuhannya, sesama manusia dan lingkungannya. Penerapan pendidikan karakter berbasis 5 karakter wajib taruna

Heka Fitria Fujiy, dkk. Penerapan Model Pendidikan Karakter Berbasis

"5 Karakter Wajib Taruna" SMK Negeri 13 Malang 
diterapkan dalam kegiatan sehari-hari dari jam pembelajaran dimulai hingga berakhir hal tersebut wajib dilaksanakan dan melekat pada diri setiap taruna-taruni. 5 karakter wajib taruna tersebut masing-masing sebagai daya pendorong untuk melakukan sikap dan perbuatan yang baik sehingga menjadi suatu pembiasaan pada diri setiap taruna, dalam penerapannya diberi pencegahan yang sifatnya preventif.

Reward diberikan melalui point yang ditulis pada halaman catatan prestasi pada buku saku dan point tersebut disesuaikan dengan prestasi yang diraih.

Pendidikan karakter berbasis 5 karakter wajib taruna harus menjadi satu kesatuan dalam diri taruna-taruni, bagi yang tidak melaksanakan pendidikan karakter berbasis 5 karakter wajib taruna akan diberikan sanksi, mulai sanksi ringan hingga berat.

Sanksi diberikan kepada taruna yang tidak memakai atribut lengkap atau seragam tidak sesuai akan mendapatkan sanksi berupa pus up dan scot jump, jenis pelanggaran tersebut kategori jenis pelanggaran ringan dengan point 1 .

Penerapan pendidikan karakter berbasis 5 karakter wajib taruna diterapkan pada saat kegiatan pembelajaran dimulai hingga berakhir, penerapan dimulai dari kegiatan apel pagi hingga berakhirnya proses pembelajaran dsekolah. Taruna dibiasakan untuk dapat menerapkan pendidikan karakter berbasis 5 karakter wajib taruna dan apabila ada taruna yang tidak bisa menerapkan maka akan mendapatkan sanksi melalui buku saku. Taruna yang tidak melaksanakan dan membiasakan diri dalam penerapan pendidikan karakter berbasis 5 karakter wajib taruna akan mendapatkan sanksi melalui buku saku.
Penerapan pendidikan karakter berbasis 5 karakter wajib taruna adalah untuk mendisiplinkan seluruhnya, baik itu disiplin dalam hal spritual, sikap, maupun perbuatan, dengan membiasakan mendsiplinkan taruna setiap hari maka akan terbiasa dengan berbagai aplikasi dari penerapan pendidikan karakter berbasis 5 karakter wajib taruna. Penerapan pendidikan karakter berbasis " 5 karakter wajib taruna” adalah sebagai upaya untuk memperkenalkan nilai-nilai positif yang penting dalam hidup seorang taruna-taruni. "5 karakter wajib taruna” tersebut untuk dapat diterapkan dan diaplikasikan di sekolah dan lingkungan masyarakat yang nantinya akan dibawa sepanjang hidup. Sehingga menjadikan taruna menjadi manusia yang menjunjung tinggi harkat, martabat dan jadi diri taruna yang berkepribadian baik, baik pribadi terhadap Tuhan, lingkungan dan sesama manusia.

Penerapan pendidikan karakter berbasis "5 karakter wajib taruna" diterapkan dalam kegiatan sehari-hari, dari taat, jujur, disiplin, bekerjasama dan berprestasi. 5 karakter tersebut diterapkan dalam semua aspek kehidupan di lingkungan sekolah melalui kegiatankegiatan yang dimulai dari jam 06.30 WIB yaitu dari proses pembelajaran dimulai hinga berakhir jam 15.30 WIB, selama proses pembelajaran berlangsung 5 karakter wajib taruna menjadi 1 kesatuan pada diri setiap taruna. Untuk memberikan pencegahan agar tidak terjadi pelanggaran kedisiplinan siswa dipantau dengan buku disiplin taruna (buku saku) dan al kays untuk mencatat ibadah taruna serta diberikannya sanksi ringan hingga berat selama penerapan pendidikan karakter berbasis 5 karakter wajib taruna. 
Kendala yang dihadapi dalam Penerapan Pendidikan Karakter Berbasis 5 Karakter Wajib Taruna SMK Negeri 13 Malang

Penerapan pendidikan karakter berbasis 5 karakter wajib taruna SMK Negeri 13 Malang, tentunya sudah berjalan namun dalam perkembanganya tentu tidak lepas dari adanya kendala yang terjadi. Kendala yang dimaksud adalah faktor penghambat yang dapat menghambat jalanya program tersebut. Berdasarkan hasil wawancara dengan beberapa informan, ditemukan beberapa kendala yang dihadapi dalam penerapan pendidikan karakter. Kendala tersebut adalah kecenderungan taruna menolak untuk diajak dalam menerapkan pendidikan karakter berbasis 5 karakter wajib taruna karena bagi mereka itu adalah sesuatu yang berat.

Kendala yang dihadapi dalam penerapan pendidikan karakter berbasis 5 karakter wajib taruna diantaranya: 1) Belum adanya kesadaran, sehingga kecenderungan taruna sulit menerapkan pendidikan karakter berbasis 5 karakter wajib taruna, 2) Masih adanya guru yang kurang mendukung, 3) Kurang pengawasan orang tua dirumah, sehingga hal-hal tersebut menjadi kendala yang dihadapi dalam penerapan pendidikan karakter berbasis 5 karakter wajib taruna SMK Negeri 13 Malang.

Solusi yang dapat dilakukan dalam Penerapan Pendidikan Karakter berbasis 5 Karakter Wajib Taruna SMK Negeri 13 Malang

Setiap kendala-kendala yang dihadapi tentunya perlu dicari jalan keluar yang terbaik. Begitu pula kendala yang dihadapi dalam penerapan pendidikan karakter berbasis 5 karakter wajib taruna SMK Negeri 13 Malang, diantaranya dengan memberikan pembinaan kepada bapak/ ibu guru agar mereka dapat memberikan teladan karena penerapan pendidikan karakter sebenarnya adalah keteladan, meskipun 5 karakter wajib taruna diucapkan setiap senin oleh anak-anak akan tetapi tanpa keteladanan bapak/ibu guru penerapan pendidikan karakter berbasis 5 karakter wajib taruna tidak akan berekembang dengan baik, karena taruna-taruni mereka juga melihat model dan contoh.

Selain pembinaan kepada bapak/ibu guru, penerapan pendidikan karakter berbasis 5 karakter wajib taruna juga perlu didukung oleh semua pihak, baik itu instansi yang ada disekolah, pihak orang tua, kemudian kesadaran diri taruna jadi pembinaan tidak hanya dilakukan kepada bapak/ibu guru saja tetapi, orang tua dan yang paling penting pembinaan terhadap taruna-taruni ketika mereka membaca 5 karakter wajib taruna otomatis mereka harus menerapkannya, sebab 5 karakter wajib taruna akan sulit untuk diterapkan tanpa dukungan dari semua pihak.

Penjelasan Waka Kurikulum solusi yang dapat diambil dalam penerapan pendidikan karakter berbasis 5 karakter wajib taruna yaitu melalui buku saku, dan hal lain tak kalah penting adalah kearah wali kelas, wali kelas diharap memahami karakter dan kondisi taruna serta melakukan sosialisasi dengan orang tua terkait 5 karakter wajib taruna dan meminta untuk bekerjasama mengawasi tarunataruni selama berada dirumah. Solusi yang dapat dilakukan dalam penerapan pendidikan karakter berbasis 5 karakter wajib taruna SMK Negeri 13 Malang adalah sebagai berikut:

1) Memberikan pencegahan agar tidak terjadi pelanggaran, kedisiplinan taruna dipantau dengan buku disiplin taruna (buku saku), kegiatan ibadah dengan buku kontrol ibadah (al-kays).

Heka Fitria Fujiy, dkk. Penerapan Model Pendidikan Karakter Berbasis

"5 Karakter Wajib Taruna" SMK Negeri 13 Malang 
Pencegahan melalui buku saku diberikan dengan cara memberikan riwed berupa pont prestasi sesuai dengan jenis prestasi yang didapat oleh taruna, sebaliknya bila mereka melakukan pelanggaran maka mereka juga akan mendapatkan sanksi berupa pint pelanggaran melalui buku saku dan sanksisanksi lain sesuai dengan pelanggaran yang mereka lalukan hal ini dilakukan agar tidak terjadi pelanggaran-pelanggaran selama proses penerapan pendidikan karakter berbasis 5 karakter wajib taruna.

Apabila buku saku diberikan untuk pencegahan semua penerapan kegiatankegiatan pendidikan karakter berbasis 5 karakter wajib taruna, buku al-kays diberikan hanya untuk penerapan dalam kegiatan keagamaan saja buku ini diisi saat taruna melakukan ibadah shalat dhuha dan dzuhur di sekolah dengan meminta tanda tangan guru pendamping atau kepala sekolah dan selama mereka dirumah ibadah mereka akan dikontrol orang tua dengan cara meminta tanda tangan orang tua.

2) Komunikasi antara pihak sekolah dan orang tua dilakukan pertemuan selama 1 bulan sekali dengan melakukan istiqosah bersama.

Komunikasi antara pihak sekolah menjadi solusi yang dilakukan untuk menghadapi kendala yang terjadi, agenda tersebut harus rutin dilakukan sebab dengan melakukan komunikasi dan koordinasi maka orang tua akan membantu pengawasan taruna selama berada dirumah.

Komunikasi antara pihak orang tua dilakukan untuk menjalankan programprogram sekolah, termasuk program penerapan pendidikan karakter berbasis “5 karakter wajib taruna”. Program tersebut dilaksanakan salah satunya dengan melalukan istiqosah bersama yang dilanjutkan evaluasi dari seluruh program hal ini dilakukan agar ada koordinasi antara pihak sekolah dengan pihak orang tua wali murid.

3) Melakukan konsultasi kepada tarunataruni yang dilakukan oleh staff batalyon

Dilakukan pada saat di luar kelas ataupun konsultasi langsung ke kelas-kelas hal itu dilakukan untuk melakukan koordinasi antara staff batalyon dengan seluruh taruna serta mengetahui bagaimana kedisiplinan taruna-taruni selama proses penerapan pendidikan karakter berbasis "5 karakter wajib taruna".

4) Kontrol sikap taruna melalui bimbingan konseling

Bimbingan konseling dilakukan sebagai upaya untuk mengontrol sikap taruna, bimbingan konseling dilakukan melalui kegiatan belajar mengajar dan dilakukan di luar jam pembelajaran. Bimbingan konseling perkelas dilakukan 1 minggu sekali sesuai jadwal pembelajaran dengan memberikan materi motivasi, sikap, ataupun perilaku apabila di luar jam belajar mengajar taruna bisa konsultasi langsung pada saat jam istirahat berlangangsung. Kontrol dilakukan juga bagi taruna-taruni yang bermasalah untuk dibina dengan baik agar tidak mengulangi kesalahannya. Bimbingan konseling tersebut dilakukan sebagai upaya untuk mendalami dan mengerti sikap dan perilaku taruna.

\section{SIMPULAN}

Penerapan pendidikan karakter berbasis 5 karakter wajib taruna diterapkan dalam kegiatan sehari-hari, dari taat, jujur, disiplin, bekerjasama dan berprestasi. 5 karakter tersebut diterapkan dalam semua aspek kehidupan di lingkungan sekolah melalui kegiatan-kegiatan yang dimulai dari jam 06.30 WIB yaitu dari proses pembelajaran dimulai hinga berakhir jam 
15.30 WIB, selama proses pembelajaran berlangsung 5 karakter wajib taruna menjadi 1 kesatuan pada diri setiap taruna. Untuk pencegahan agar tidak terjadi pelanggaran kedisiplinan taruna dipantau dengan buku disiplin taruna (buku saku) dan kegiatan ibadah melalui buku kontrol ibadah (al-kays) serta pemberian sanksi dari ringan hingga berat bagi yang tidak menerapkan. Pendidikan karakter berbasis 5 karakter wajib taruna diterapkan dalam kegiatan-kegiatan dari: 1) Apel pagi; 2) Imtaq, Tutor sebaya, Hatam Al-Qur'an bagi muslim dan Kebaktian bagi tarunataruni non muslim; 3) Pengecekan seragam, atribut dan buku saku oleh staff batalyon; 4) Sholat Dhuha dan Shalat Dzuhur Berjama'ah; 5) Memberikan Penghormatan kepada guru dan atasan (senior); 6) Kegiatan Ketarunaan; 7) Sholat jum'at dan Kajian keputrian; 8) Upacara Bendera; 9) Setiap sudut sekolah dipasang dengan kata-kata Mutiara, Semboyan dan Himbauan; 10) Merayakan Hari Besar Keagamaan; 11) Laporan kepada guru sebelum dimulai pembelajaran; 12) Kegiatan Ekstakurikuler; 13) Masuk kelas sesuai dengan standar Taruna; 14 Kegiatan Pembelajaran berbasis lesson study; 13) Kegiatan LDK; 15 Kegiatan aksi hijau.

Kendala yang dihadapi dalam penerapan pendidikan karakter berbasis 5 karakter wajib taruna, diantaranya: 1) Belum adanya kesadaran, sehingga kecenderungan taruna sulit menerapkan pendidikan karakter berbasis 5 karakter wajib taruna, 2) Masih adanya guru yang kurang mendukung, 3) Kurang pengawasan orang tua dirumah, sehingga hal-hal tersebut menjadi kendala yang dihadapi dalam penerapan pendidikan karakter berbasis 5 karakter wajib taruna SMK Negeri 13 Malang.
Solusi yang dapat dilakukan dalam penerapan pendidikan karakter berbasis 5 karakter wajib taruna SMK Negeri 13 Malang adalah sebagai berikut: 1) Memberikan pencegahan agar tidak terjadi pelanggaran, kedisiplinan taruna dipantau dengan buku disiplin taruna (buku saku), kegiatan ibadah dengan buku kontrol ibadah (al-kays), 2) Komunikasi antara pihak sekolah dan orang tua dilakukan pertemuan selama 1 bulan sekali dengan melakukan istiqosah bersama, 3) Melakukan konsultasi kesetiap kelas yang dilakukan oleh staff batalyon untuk mendisiplinkan taruna, 4) Kontrol sikap taruna melalui bimbingan konseling, 5) Seluruh elemen sekolah terutama taruna SMK Negeri 13 Malang dan guru ikut menegakkan 5 karakter wajib taruna. Dengan demikian kendala-kendala yang dihadapi dalam penerapan pendidikan karakter berbasis 5 karakter wajib taruna dapat teratasi.

Berdasarkan hasil penelitian Penerapan pendidikan karakter berbasis 5 karakter wajib taruna, maka penulis memberikan saran sebagai berikut:Penerapan pendidikan karakter berbasis 5 karakter wajib taruna yang telah diterapkan oleh sekolah harus terkonsep dengan baik, karena sekolah merupakan pendidikan formal sebagai wadah untuk memberikan pembinaan kualitas diri dan jati diri generasi penerus bangsa. Sekolah perlu memberikan layanan pendidikan dalam bidang pengajaran, pelatihan dan pembinaan sebagai upaya untuk menjadikan generasi-generasi muda menjadi manusia yang berkarakter kuat.

Terkait kendala yang terjadi sekolah perlu memberikan pemahaman terhadap penerapan pendidikan karakter berbasis 5 karakter wajib taruna kepada taruna itu sendiri. Pendidikan karakter harus dikonsep 
dan dijalankan oleh seluruh warga sekolah. Komunikasi dan koordinasi harus intensif untuk membahas tentang kebijakan pendidikan karakter berbasis 5 karakter wajib taruna yang diterapkan oleh SMK Negeri 13 Malang, sehingga semua warga sekolah memahami, mengerti dan dapat mendukung penerapan pendidikan karakter berbasis 5 karakter wajib taruna.

Solusi dalam mengatasi kendala penerapan pendidikan karakter berbasis "5 karakter wajib taruna" yaitu dengan menciptakan suasana kedisiplinan untuk seluruh warga sekolah agar konsep dan penerapan dapat berjalan beriringan sehingga hal tersebut menjadi budaya positif sekolah.

\section{DAFTAR PUSTAKA}

Barnawi, Arifin M. 2012. Strategi \& Kebijakan Pembelajaran Pendidikan Karakter.Jogjakarta : Ar-Ruzz Media.

Fadlillah M, Khorida Mualifatuff Lilif. 2013. Pendidikan Karakter Usia Dini. Jogjakarta : Ar-Ruzz Media.

Muslich, Masnur. 2011. Pendidikan Karakter : Menjawab tantangan Krisis Multidimensional. Jakarta: Bumi Aksara.

Sugiyono. 2010. Metode Penelitian Pendidikan Pendekatan Kuantitatif, kualitatif, dan $R \& D$. Bandung : Alfabeta.

Undang-Undang No. 20 tahun 2003 pada pasal 3

Zuriah, Nurul. 2009. Metedologi Penelitian Sosial dan Pendidikan (Teori Aplikasi). Jakarta : PT. Bumi Aksara

Zuriah, Nurul, dkk. 2011. Pendidikan Karakter Berbasis Budaya Akademik, Reliqius, dan Manusiawi. (PKBB AREMA). Malang : UMM Press.

Jurnal Civic Hukum Volume 3, Nomor 2, November 2018, hal. 149-162 